\title{
Erratum to: 'Left ventricular twist mechanics and its relation with aortic stiffness in chronic kidney disease patients without overt cardiovascular disease'
}

Samir Sulemane $1^{*}$, Vasileios F. Panoulas², Klio Konstantinou², Athanasios Bratsas², Julia Grapsa ${ }^{3}$, Frederick W. Tam4, Edwina A. Brown ${ }^{4}$ and Petros Nihoyannopoulos ${ }^{1}$

After the publication of this work [1], it was brought to the authors' attention that the author list on the final manuscript was incomplete.

It read as Samir Sulemane, Vasileios F. Panoulas, Klio Konstantinou, Athanasios Bratsas, Frederick W. Tam, Edwina A. Brown and Petros Nihoyannopoulos.

The correct author list should have included Dr Grapsa and is now included here.

Samir Sulemane, Vasileios F. Panoulas, Klio Konstantinou, Athanasios Bratsas, Julia Grapsa, Frederick W. Tam, Edwina A. Brown and Petros Nihoyannopoulos.

\section{Competing interests}

The authors declare they have no competing interests.

\section{Authors' contributions}

All authors made significant contributions and participated sufficiently in the present manuscript. SS, VP, JG, AB and PN were involved in the conception of the study. SS, VP, KC and $A B$ were involved in recruitment, data collection, data (statistical) analysis and were also involved in the writing process and critical analyses. FT and EB were involved in the recruitment process and manuscript review. PN was involved in all aspects of this manuscript. All authors read and approved the final manuscript.

\section{Acknowledgement}

Samir Sulemane received a doctoral research grant from Fundação para a Ciência e Tecnologia (FCT) under the grant number SFRH/BD/73646.

\section{Author details}

${ }^{1}$ Imperial College London, National Heart and Lung Institute, London, UK.

${ }^{2}$ Imperial College Healthcare NHS, Hammersmith Hospital, London, UK. ${ }^{3}$ Imperial College, London, UK. ${ }^{4}$ Imperial College Renal and Transplant

Centre, Hammersmith Hospital, London, UK.

Received: 15 April 2016 Accepted: 15 April 2016

Published online: 19 April 2016

\footnotetext{
* Correspondence: s.sulemane11@imperial.ac.uk

${ }^{1}$ Imperial College London, National Heart and Lung Institute, London, UK
}

\section{Reference}

1. Sulemane S, Panoulas VF, Konstantinou K, Bratsas A, Tam FW, Brown EA, Nihoyannopoulos $P$. Left ventricular twist mechanics and its relation with aortic stiffness in chronic kidney disease patients without overt cardiovascular disease. Cardiovasc Ultrasound. 2016;14:10.
Submit your next manuscript to BioMed Central and we will help you at every step:

- We accept pre-submission inquiries

- Our selector tool helps you to find the most relevant journal

- We provide round the clock customer support

- Convenient online submission

- Thorough peer review

- Inclusion in PubMed and all major indexing services

- Maximum visibility for your research

Submit your manuscript at

www.biomedcentral.com/submit

\section{Biomed Central}

